\title{
A CLÍNICA ODONTOLÓGICA E O PACIENTE IDOSO
}

Isis Nogara OLIVEIRA, Adriana BELOTI

A melhoria das condições básicas da vida e o avanço técnico-científico têm permitido cada vez mais e de forma socializada, o aumento da expectativa de vida da população. Esses fatores, associados as medidas preventivas,permitem não só a manutenção da saúde geral do paciente idoso como também influenciam nas condições bucais, determinando uma maior demanda por serviços odontológicos nessa faixa etária. O paciente geriátrico pode apresentar condições que predispõe ao desenvolvimento de cáries dentárias, doença periodontal e alterações nas diversas estruturas que compõem o sistema estomatognático. A saúde bucal uma vez comprometida, afeta a saúde geral, seja por uma ação direta ou indireta, comprometendo a nutrição, a fala e o bem estar físico e social do individuo. Algumas possibilidades para o tratamento reabilitador bucal bem como a manutenção da saúde do mesmo devem ser discutidas com objetivo de favorecer o seu planejamento de acordo com as estratégias estabelecidas na avaliação clinica, por meio de procedimentos condizentes com as condições do paciente.

Palavras-chave: Idoso; Saúde bucal; Cáries Dentárias. 